I Université de Vincennes - Paris 8, Institut d'Etudes Européennes (IEE),

Saint-Denis, France

aquemin@univ-paris-8.fr

Alain Quemin'

\title{
THE IMPACT OF NATIONALITY ON THE CONTEMPORARY ART MARKET
}

The sociology of art emerged in its present conception in I96os France in the form of a double tradition, influenced by two leading authors who developed substantial empirical research in the area: Raymonde Moulin (Moulin, I987), who studied the art market, and Pierre Bourdieu and his collaborators (Bourdieu et al., I997), who provided a major contribution with their innovative and seminal studies of visitors. Empirical research has since enabled the sociology of art to develop in remarkable fashion, first in France and then internationally (Villas Bôas \& Quemin, 20I5). But although globalization began to attract considerable attention from social scientists in the I99os (Bartelson, 2000; Therborn, 2000), the theme did not really take hold in the sociology of art at first, and empirical analyses remained limited for many years before expanding significantly (Bellavance, 2000; Quemin, 200I, 2002a, 2006, 20I 3a, 2013b; Van Hest, 20I 2, Velthuis, 20I3). In this article, ${ }^{\mathrm{I}}$ I study the impact of nationality and territory - the artist's country of residence - on artistic success (Bowness, I989) and the process of consecration, utilizing empirical data on artists and the players who promote them. This will allow me to show that even at a time when globalization is supposed to be the rule in the art sector, national entities still matter and a strong hierarchy still exists between nations. In my research I have conducted more than Ioo formal interviews and also identified and analyzed a dozen different 'indigenous' rankings of the most famous/visible/recognized artists, some of which have been published for decades now, meaning 
that 70 different editions of rankings relating to contemporary art were analyzed in total. ${ }^{2}$ In this article, however, I focus on just three major rankings two lists of artists: the Kunstkompass and the Capital Kunstmarkt Kompass; and one listing of the most powerful players from the international contemporary art world: the ArtReview Power Ioo - in order to illustrate the extremely uneven distribution of success and power between different countries in the contemporary art domain and try to understand what might explain this situation. Finally, a number of other economic rankings are mentioned in order to compare their results with those of the previous lists.

\section{THE FIRST RANKING OF ARTISTS AND CONTEMPORARY ART} AS A CATEGORY

\section{From early lists to rankings in art history}

As soon as art history emerged as a discipline, authors had to evaluate the aesthetic value of works and decide who the most important 'visual artists' were (i.e. painters and sculptors at that time). In The Lives of the Most Excellent Painters, Sculptors and Architects (I550), Italian artist, art critic and historian Giorgio Vasari selected dozens of artists, ${ }^{3}$ yet never attempted to rank them, much less attribute marks in order to quantify or objectify aesthetic quality. Later in history, French art critic Roger de Piles in his Cours de peinture par principes (1708) selected 57 dead or living significant artists to comment on their works and award them marks - out of 20 - on four criteria: composition, drawing, colors and expressivity. However, although this quantification would have enabled the artists to be compared and ranked had each of their marks been added up, it never occurred to him to do so.

Things changed radically in 1970 with the first ever ranking of artists to be published on a yearly basis, the Kunstkompass (the 'art compass' in German). The rankings were published by Willy Bongard, an economic journalist with a strong interest in art, in the German economic magazine Capital (Verger, I987; Rohr-Bongard, 200I). One fact should be stressed: the first ranking of artists appeared simultaneously with the emergence of contemporary art as a category ${ }^{4}$ at the historical and seminal exhibition When Attitudes Become Form, curated by Harald Szeemann at Bern Kunsthalle in Switzerland, in I969. It seems that with the emergence of the new form of art, or 'contemporary creation,' it immediately became necessary to reduce the uncertainty concerning its value. ${ }^{5}$

From I 970 until 2007, the Kunstkompass was published regularly on an almost yearly basis in Capital before moving in 2008 to another German economic journal, Manager Magazin, which also published the list annually. Capital did not stop publishing a ranking of contemporary artists, though, as it developed a partnership with a firm, Artfacts, to publish a second ranking of con- 
temporary visual artists, also on a yearly basis: Capital Kunstmarkt Kompass! The lengthy existence of the Kunstkompass, combined with the more recent appearance of a competing ranking, the Capital Kunstmarkt Kompass, are a clear sign of the strong and persistent social demand for such rankings of living artists, designed to reduce the uncertainty over value in the contemporary art scene (Moulin \& Quemin, I993). ${ }^{6}$

\section{The Kunstkompass methodology}

In any kind of ranking, the results depend directly on the methodology used, which in turn reflects a particular view of the way that the art world works. A brief presentation is therefore required of the method used by these two major rankings to compile the list of the top Ioo visual artists in the world each year. Since its creation in 1970, the Kunstkompass has been based on a system of points allocated to different kinds of artist visibility. The system has evolved slightly over time and is not entirely transparent. It has only been made public on a handful of occasions.? Nevertheless, it can be summarized schematically as follows. Artists receive points on three major occasions:

- Solo-exhibitions in museums or contemporary art centers: the more prestigious the institution, the greater the number of points. A solo show at MoMA in New York City, for example, or the Tate Modern in London, or the Centre Georges Pompidou in Paris, will yield a very high number of points, whereas other solo shows in other less important but still significant institutions will generate fewer points.

- Participation in collective exhibitions such as biennials or in collective shows in museums or contemporary art centers. Once again, the more prestigious the institution, the higher the number of points (for instance, participation in the most prestigious biennials such as Venice's in Italy or the Kassel Documenta in Germany will yield a very high number of points, whereas other significant biennials organized in other cities will also qualify, but with fewer points). Since a solo show gives more visibility to artists and plays an even greater role in their consecration process (Quemin, 2013b, 2013C), the most important solo shows weigh more than participation in the most prestigious collective exhibitions.

- Reviews in the most influential contemporary art magazines such as Flash Art, Art in America and Art Forum.

A certain number of points are allocated to each previous occasion of visibility and at the end of the year the points are totaled, allowing the Kunstkompass team to publish its annual ranking of the top roo contemporary (living) artists in the world.

It is important to mention here that almost since its inception, the Kunstkompass has been criticized for showing a strong bias in favor of Germany (overrepresenting German institutions among certifying ones and attributing them 
coefficients often deemed too high relative to their real weighting in the international contemporary art world; I return to this point later) and, to a lesser extent, in favor of neighboring countries within its cultural zone of influence (such as Austria). Nonetheless, the ranking has existed for more than 40 years now and its general methodology has remained essentially the same.

\section{The Artfacts methodology}

Unlike the team responsible for compiling the Kunstkompass, Artfacts uses a much broader range of certifying institutions and, in particular, includes many events associated with the art market: private contemporary art galleries, public institutions (with or without a collection of their own: that is to say, museums and contemporary art centers), biennials and triennials, other spaces for temporary exhibitions, contemporary art fairs, auctions, art hotels, art reviews, journals and magazines, art books, art schools, festivals, non-profit organizations, and even art management institutions and private collections. Although it cannot be completely exhaustive, this extremely wide survey of information limits the risk of certain biases.

Whereas some institutions are crucial to the consecration process, others appear to be more secondary or even marginal. It is thus important that the coefficients attributed to each of the different institutions reflect this difference. With this in mind, Artfacts has created an algorithm that determines the weight of each institution based on the fame of the artists associated with it. In essence 'network points' are allocated. All artists collected by museums and represented by galleries receive points which are then allocated to the institutions collecting or representing the same artists: these 'network points' thus reflect the reputation of the institution concerned. An artist receives points for each exhibition in a museum or gallery. Although from a logical viewpoint it may seem surprising that artists and institutions mutually influence each other's weighting and hence the position of artists in the ranking, sociological analysis has shown that in the world of contemporary art, not only artists and galleries (and gallery owners) mutually influence each other's reputations, so do artists and institutions (Moulin, I992; Moulin \& Quemin, I993). This is precisely one of the major interests of the method elaborated by Artfacts: the attempt to reflect this peculiarity of the contemporary art world. Unlike other methodologies, such as Kunstkompass's, in which subjectivity plays an important role in determining coefficients and generates very significant biases (leading, as we shall see, to an overrepresentation of German artists), the coefficients used by Artfacts are not effectively set once and for all, or only very occasionally reconsidered, as is the case with the Kunstkompass. Instead they are constantly actualized - that is, every week - by the algorithm, taking into account the certifying power of the institutions, based in turn on the reputation of the artists associated with them. Moreover, the scope of the database is a 
key aspect, with no less than I00,000 ranked artists in March 20I4 and 300,000 more referenced in the database without any ranking! As we shall see, even in this second ranking the presence of Western artists is overwhelming. This cannot be explained only by the fact that they or their galleries are unaware of the existence of Artfacts and thus fail to let the company know about artists' activities. It seems that most information is collected indirectly by Artfacts and not transmitted directly by artists or their galleries. Hence, the more connected to the core of the art world a gallery or an artist is, the more likely artists are to appear in the database and to receive a high score. All artists whose positions in the art world are more or less peripheral - whether because they are non-Western and/or are represented by a non-Western gallery, or because, although they belong to the Western world, they occupy a somewhat marginal position on the contemporary art scene - will have limited visibility in the contemporary art world. Besides, it would be somewhat naive to believe that non-Western artists or galleries are simply unaware of the existence of Artfacts because of their geographical peripheral position. While doing fieldwork in both Brazil and the United Arab Emirates I was able to see how gallerists were perfectly aware of the existence of Artfacts and even used it in my presence when I mentioned artists that they did not know or when they tried to objectivize the visibility of their own artists during our discussions.

As a private firm, Artfacts does not publish or even provide on request the construction mode for its algorithm, which is protected by industrial secrecy. This fact is frustrating for any social scientist wishing to evaluate the rigorousness of the methodology used. However it was possible to reconstitute some of the coefficients used, which revealed its high level of efficiency and relevance. The internationally recognized Austrian-French gallery Thaddaeus Ropac, for example, weighed over 3 times more than the French-Swiss-Luxembourgian gallery Bernard Ceysson. Although the main ranking is based on the number of points accumulated since the indicator was first created in I999, the ranking is not much different - at the top of the list - from the one that would be produced by considering only the number of points accumulated over the previous twelve months: success generally begets success, comprising a good illustration of Robert Merton's Matthew effect (Merton, I968).

\section{THE IMPACT OF NATIONALITY AND COUNTRY OF RESIDENCE ON ARTISTIC SUCCESS}

For many years now, I have used the 'indigenous' Kunstkompass indicator to study globalization in contemporary art (Quemin, 200I, 2002a, 2002b, 2006, 20I3a, 20I3b, 2013c). As early as 2000, with the aim of studying globalization in the visual arts sector, I began calculating each country's share of the total points allocated by Kunstkompass each year - although the ranking is indi- 
vidual and artists belonging to the same country are not aggregated in the list itself. Since then, the method has regularly produced similar results year after year and has given rise to what could be likened to a 'social law,' in Durkheimian terms, revealing a strong hierarchy among countries that has evolved very little over time, once again reflecting that success generally begets success, both individually and nationally. This can be explained by the strategies developed by various players from the contemporary art world, whether these strategies are conscious or not: for museum directors and curators, the prestige of their institutions will directly benefit the status of the artists being shown which, in turn, as my data shows, is connected to their country of origin or residence. This produces a path-dependency, in which the reputation of institutions can gradually rise, in turn impacting on the local artists that they exhibit, and vice-versa. For collectors, their investment in art is safer if they choose artists whose prices may increase, which is more often the case - or at least thought to be more often the case - for American and German artists, for instance (Quemin, 2002). As we shall see, prestigious contemporary art auctions show a very strong concentration of American, German and British artists, and auctions play a major role in pushing up record prices. Hence the national concentration effects that, among other factors, reflect these choices.

The first point to be observed in the table I is the number of countries appearing from 2007 to 2012 . To these we can add the figures for the period running from 1994 to 2006 in the Table 2.

Despite the widespread idea that today's contemporary art world has become globalized - and notwithstanding a slight increase (from I6 to 23) in the number of countries represented from the mid-Ig9os to the start of the 2000 - the number of countries participating in the international contemporary art scene has been fairly stable since the beginning of the millennium ${ }^{9}$ and remains very limited given that the world has between I 90 and 200 different nations.

Furthermore, the weight of the few countries that appear in Table I is very uneven. The USA and Germany come far ahead of all other nations with around $30 \%$ of total contemporary international artistic production for each of them. They are followed by the United Kingdom with a share that is situated around 9 or I0\% each year. Then come France, Switzerland, Italy and Austria, at a marked distance from the three preceding leading nations, as the share of the four following countries is situated around 2,5 to $4 \%$ only. The percentage of all other countries appearing in Table $\mathrm{I}$ is lower still and generally due to a single artist. This makes the presence of these countries on the international contemporary art scene particularly insubstantial.

What changes if we now 'correct' the Kunstkompass data listing the artists' nationalities by focusing instead on countries of residence? 


\begin{tabular}{|c|c|c|c|c|c|c|}
\hline Year & 2007 & 2008 & 2009 & 2010 & $20 I I$ & 2012 \\
\hline USA & 30.0 & 28.6 & 26.6 & $3 \mathrm{I} .2$ & 30.4 & 30.5 \\
\hline Germany & 31.6 & 32.0 & 30.5 & 31.7 & 29.0 & 30.1 \\
\hline UK & 9. I & IO.I & $9 \cdot 3$ & I0.7 & IO.I & 9. I \\
\hline France & 4.0 & 3.8 & 0.8 & 3.7 & 3.9 & 4.0 \\
\hline Switzerland & 3.8 & 3.2 & 3.9 & 3.7 & 4.5 & 4.2 \\
\hline Italy & $3 . I$ & 2.7 & 4.4 & 2.0 & 2.0 & 2.8 \\
\hline Austria & 2.6 & 2.5 & I. 7 & 2.7 & 3.0 & 2.9 \\
\hline Canada & I.9 & 2.5 & 0.9 & I.7 & I. 8 & I.8 \\
\hline Belgium & I. 8 & I. 8 & $\mathrm{I} .2$ & I. 8 & I.9 & 2.0 \\
\hline Netherlands & I.6 & I. 5 & 0 & 0.9 & I.5 & I. 5 \\
\hline Denmark & $\mathrm{I} .4$ & I. 5 & 2.4 & 2.I & 2.2 & 2.I \\
\hline South Africa & I.3 & I.4 & 1.5 & I.4 & I. 4 & 1.3 \\
\hline Russia & I.I & I.I & o & I.I & I.O & I.O \\
\hline Iran & I.I & I.O & 0 & I.O & 1.0 & I.O \\
\hline Mexico & I.O & 0.9 & o & 0.9 & 0.9 & 0.9 \\
\hline Greece & 0.9 & 0.8 & 0 & 0.8 & 0.8 & 0.9 \\
\hline Serbia & 0.8 & 0.8 & 0.8 & 0.8 & 0.8 & 0.8 \\
\hline Thailand & 0.8 & 0.8 & 0 & 0.7 & 0.7 & 0.8 \\
\hline Cuba & 0.8 & 0.7 & 0.6 & 0 & 0 & o \\
\hline Spain & 0.7 & 0.7 & 0 & 0 & 0 & o \\
\hline Ireland & 0.7 & 0 & 0.7 & 0 & 0 & o \\
\hline Brazil & 0 & 0 & 0.8 & 0 & 0 & o \\
\hline Japan & 0 & 0.7 & I.O & 0.7 & 0.7 & 0.7 \\
\hline Albania & 0 & 0.7 & 0 & 0 & 0 & o \\
\hline Romania & 0 & 0 & $\mathrm{I} .2$ & 0 & 0.7 & o \\
\hline Bulgaria & 0 & 0 & I.I & 0 & 0 & o \\
\hline Poland & 0 & o & I. 8 & 0 & 0 & o \\
\hline Czech Republic & o & 0 & 0.7 & 0 & 0.7 & o \\
\hline Algeria & 0 & 0 & I.I & 0 & 0 & o \\
\hline Israel & o & 0 & 1.5 & o & 0 & o \\
\hline Argentina & 0 & 0 & 0.8 & 0 & 0 & o \\
\hline India & 0 & 0 & 0.8 & 0 & 0.8 & 0.7 \\
\hline Pakistan & o & 0 & 0.7 & 0 & 0 & o \\
\hline Hong Kong & 0 & 0 & 0.7 & 0 & 0 & o \\
\hline China & 0 & 0 & 2.7 & 0 & 0 & 2.7 \\
\hline
\end{tabular}

Table I

Visibility of artists from the various countries represented in the Kunstkompass: 2007-201 $2^{8}$ 


\begin{tabular}{|c|c|}
\hline Year & $\begin{array}{r}\text { Number of countries in } \\
\text { the Kunstkompass }\end{array}$ \\
\hline I994 & I6 \\
\hline I995 & I7 \\
\hline I996 & I7 \\
\hline I 997 & I6 \\
\hline I998 & I7 \\
\hline I999 & I9 \\
\hline 2000 & 22 \\
\hline $200 \mathrm{I}$ & 23 \\
\hline 2002 & 23 \\
\hline 2003 & 22 \\
\hline 2004 & 22 \\
\hline 2005 & 22 \\
\hline 2006 & $2 \mathrm{I}$ \\
\hline 2007 & $2 \mathrm{I}$ \\
\hline 2008 & 22 \\
\hline 2009 & 27 \\
\hline 2010 & I9 \\
\hline 20 I I & $2 \mathrm{I}$ \\
\hline 2012 & $2 \mathrm{I}$ \\
\hline \multicolumn{2}{|c|}{$\begin{array}{l}\text { Table } 2 \\
\text { Number of countries represented in the } \\
\text { Kunstkompass ranking from I } 994 \text { to } 2012\end{array}$} \\
\hline
\end{tabular}




\begin{tabular}{l|r|r}
\hline Country & Nationality & Residence \\
\hline USA & 30.5 & 36.3 \\
\hline Germany & $30 . \mathrm{I}$ & 30.5 \\
\hline UK & $9 . \mathrm{I}$ & 9.9 \\
\hline Switzerland & 4.2 & 3.2 \\
\hline France & 4.0 & 4.0 \\
\hline Italy & 2.8 & 2.5 \\
\hline Austria & 2.9 & 2.9 \\
\hline Denmark & $2 . \mathrm{I}$ & $2 . \mathrm{I}$ \\
\hline Belgium & 2.0 & 2.0 \\
\hline Canada & I.8 & I.8 \\
\hline Netherlands & I.5 & I.5 \\
\hline South Africa & I.3 & I.3 \\
\hline Russia & I.0 & 0 \\
\hline Iran & I.0 & 0 \\
\hline Mexico & 0.9 & 0.9 \\
\hline Greece & 0.9 & 0 \\
\hline Serbia & 0.8 & 0 \\
\hline Thailand & 0.8 & 0 \\
\hline Japan & 0.7 & 0.4 \\
\hline India & & 0 \\
\hline China & 0.7 & 0.7 \\
\hline & & \\
\hline
\end{tabular}

Table 3

Visibility of artists from different countries in the Kunstkompass in 201 2: comparison of results by nationality and country of residence 


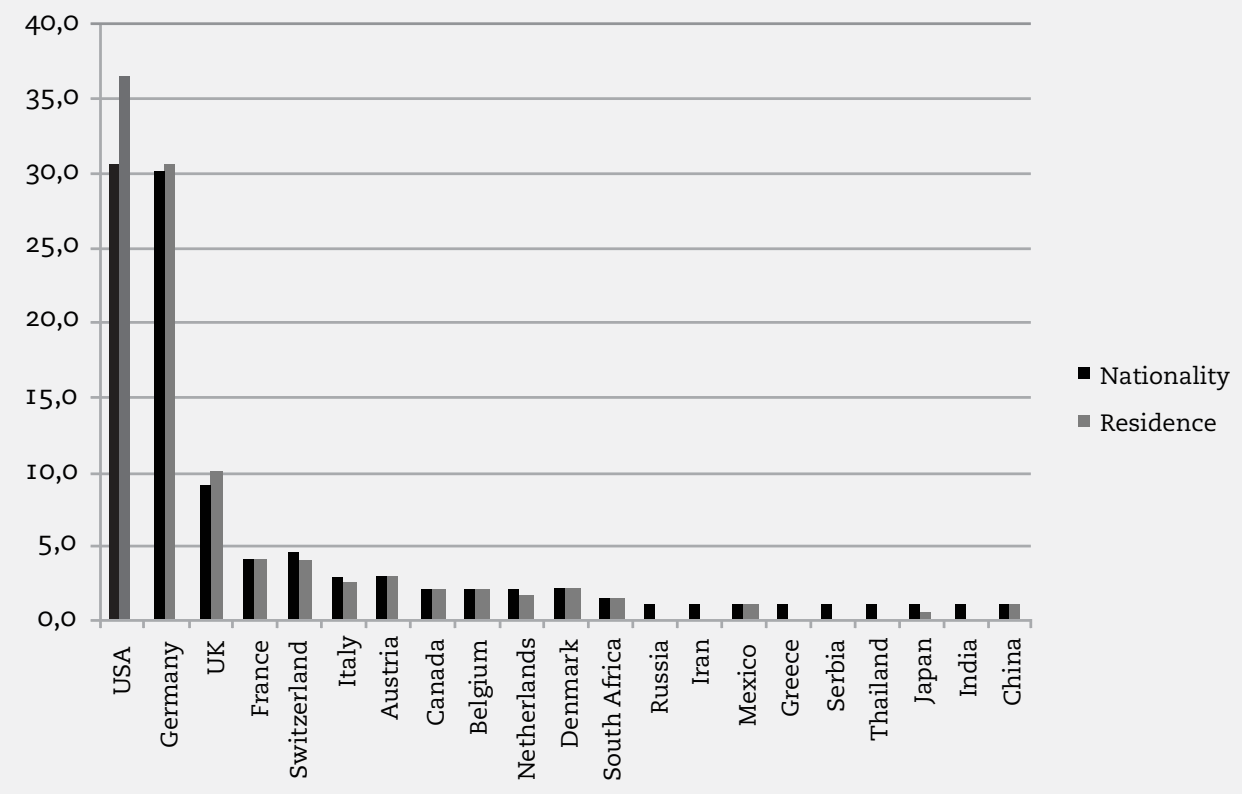

Graph I

Country share in the Kunstkompass in 2012

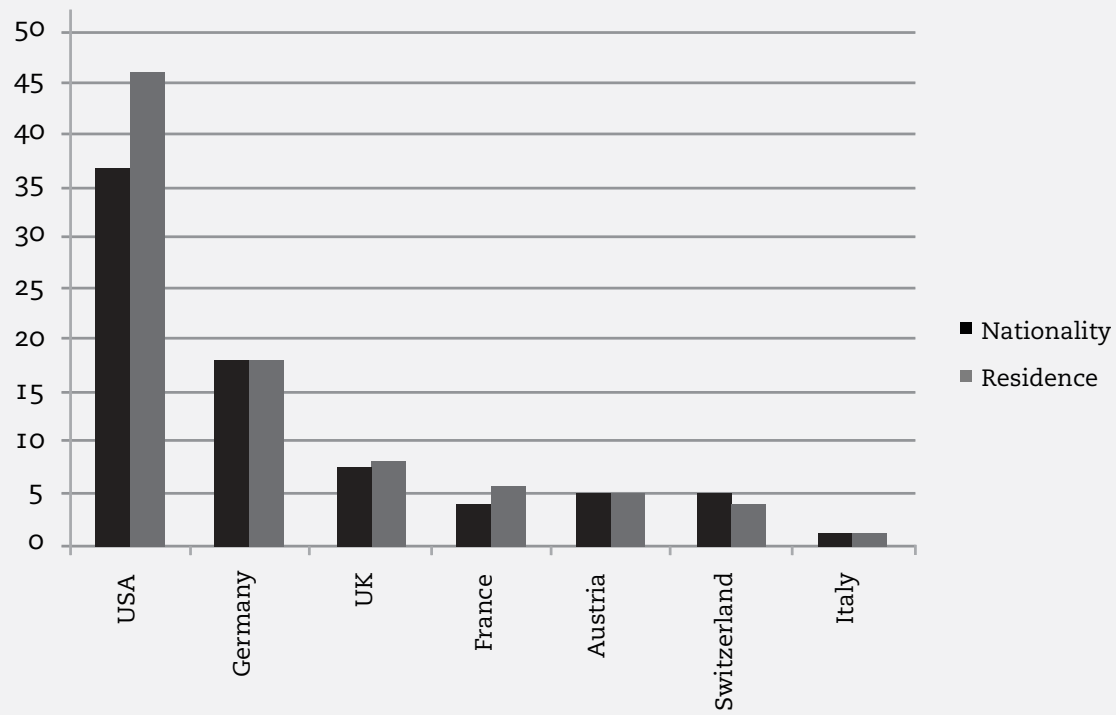

Graph 2

Top set of countries in the Artfacts ranking in 20I 2: nationality and residence 


\begin{tabular}{l|r|r}
\hline Country & $\begin{array}{r}\text { Nationality } \\
\text { (top 7 countries) }\end{array}$ & Residence \\
\hline USA & $37.1 \%$ & $46.2 \%$ \\
\hline Germany & I $8.2 \%$ & I $8.0 \%$ \\
\hline UK & $7.6 \%$ & $8.3 \%$ \\
\hline France & $4.4 \%$ & $5.8 \%$ \\
\hline Austria & $5.0 \%$ & $5.0 \%$ \\
\hline Switzerland & $4.9 \%$ & $4.0 \%$ \\
\hline Italy & I.7\% & I.6\% \\
\hline Canada & & $2.0 \%$ \\
\hline Belgium & & I.9\% \\
\hline Netherlands & & I.6\% \\
\hline South Africa & & I.4\% \\
\hline Denmark & & I. $3 \%$ \\
\hline Japan & & I.3\% \\
\hline Mexico & & I.0\% \\
\hline Sweden & & $0.8 \%$ \\
\hline
\end{tabular}

Table 4

The Artfacts ranking in terms of nationality and country of residence in 2012

The most important result to highlight is that the number of countries shown in Table 3 and illustrated in Graph I drops from 2I countries to... just I5! The weight of the various countries does not vary particularly except in the case of the most 'marginal,' 'peripheral' and 'exotic' nations whose direct contribution to the international contemporary art scene often vanishes completely. Those of their nationals who make it on the international art scene frequently live precisely in the USA. Thus the share of the latter country in the Kunstkompass data increases very significantly from $30.5 \%$ when nationality is considered to no less than $36.3 \%$ when country of residence is taken into account instead.

We can undertake the same procedure with the Artfacts ranking, first calculating the share of each country - in terms of artist nationality - in the total points for the top roo artists and then the number of artists residing in each country and their ranking in the hierarchy. The top of the list of represented nations is as indicated in Table 4.:

The first thing to observe is that although the Kunstkompass and Capital Kunstmarkt Kompass use very different methodologies to identify the most visible international artists, the two lists display very similar results in terms of the most important countries concentrating the highest number of these leading artists (cf. Van Hest, 20 2). Not only are the top 7 countries identical in 
both cases, but the top 3 countries in 2012 are also ranked in the same order. Although differences exist in the order of the next four countries, their share of the total for each indicator is very close in the two rankings, making it unlikely that the order would have been identical.

Unlike in the case of the Kunstkompass ranking, the United States comes far ahead in the Artfacts data (37.I\%), far above Germany (I8.2\%) since the latter does not benefit from the strong bias affecting its results in the previous case. It still comfortably outdistances the United Kingdom (7.63\%), though, followed by Austria (5.0\%) and Switzerland (4.9\%), which are slightly ahead of France (4.4\%). Although Italy occupied strong positions on the international contemporary art scene in the I970s, sustained by the renewed vigor of the trans-avant-garde during the I980s, its influence is today very limited with only I.7\% of the Artfacts indicator. Considering this ranking of the top roo visual contemporary artists, the top 7 countries on the list, all belonging to Western Europe and North America, concentrate almost $80 \%$ of the indicator!

Although the ideology of globalization with its mixing of different cultures and the supposed erasure of national borders has been very popular in the contemporary art world for the last two decades (Quemin, 200I, 2002a, $2002 b, 2006)$, and even though most actors from the art world love to believe that an artist's nationality does not matter, my analysis shows a very different reality. The international contemporary art world remains highly territorialized and hierarchized between countries, whatever source we turn to in the attempt to objectivize the phenomenon.

Already extremely pronounced in the previous Artfacts data, the phenomenon of concentration is even more extreme if we consider the different countries of residence, since artists from the 'periphery' of the international contemporary art world (Quemin, 2002b) tend to migrate to the more central countries in order to become consecrated. To study this phenomenon, I decided to 'correct' the data published by Artfacts by once again considering the country of residence and creation rather than nationality. A certain lack of precision is inevitable since artists - especially those still receiving state support and/or funding from their country of origin - do not generally want to publicize the fact that they have moved to another country in order to boost their international recognition. However, the results obtained are substantial enough to be identified here and any existing inaccuracy would be insufficient to affect the general trends that emerge.

Before presenting the table, the first and most important fact to emphasize is that, even in an era of so-called globalization, a huge majority of the world's most celebrated artists - those who are most likely to travel and leave their countries of origin - still live and create in the countries where they were born: $80 \%$ of them in fact ${ }^{\text {to }}$ (cf. Van Hest, 20I2). Endless artistic wanderlust appears to be a myth - and no artist lives in more than two countries over the long- 
term. Even today, creative activity is still very much embedded in a given territory (Quemin, 2006, 2013c). When artists travel abroad for a project, they still keep a base as their home (generally the country in which they were born). Of the top Ioo most visible artists in the world, no less than 96 live and create in just one country on a long-term basis, and only 4 in two countries! Moreover, if we examine the artists' countries of residence rather than their passport, a change occurs in just 19 cases. This figure is far from negligible but the phenomenon concerns a clear minority, and even when artists tend to move to an important international center for artistic creation and recognition, they sometimes continue to live and create part of the time in their home countries. As a matter of fact, those artists whose presence in the rankings is most unlikely due to their 'exotic' nationality have often settled for many years in the 'center' of the international contemporary art scene - that is to say, the USA, and New York in particular - and have contributed to the vitality of the American scene while boosting their chances of acquiring wider recognition in the international art world.

If we once again consider the share of each country in the total points received by the top Ioo artists in the Artfacts ranking, this time taking the countries of residence into account, the results are as appear in Table 4 and as illustrated in Graph 2. Once again, the USA comes first with nearly Io more points than when nationality is considered: $46.2 \%$, close to half of all international contemporary artistic production! This provides perfect illustration of the country's central role in today's international contemporary art scene. The USA thus comes far ahead of its usual challenger, Germany (I8.0\%), itself a fair distance from the United Kingdom (8.3\%), followed by France (5.8\%), Austria (5.0\%), Switzerland (4.0\%), Belgium (1.9\%), the Netherlands and Italy (1.6\% each), Denmark (1.3\%), Sweden (0.8\%), Canada (2\%), Mexico (I.0\%), Japan (I.3\%), and South Africa (I.4\%). Once more, it should be underlined that Western European countries (in actuality, a very small number of them) and North America account for nearly all the indicator (96.5\%!) - that is to say, almost all of contemporary artistic production at its highest level of visibility and success. Hardly any space is left either for non-Western countries or indeed for the vast majority of Western countries outside the dozen nations shown in the previous table.

Additionally, it should not be underestimated that the flows of international migrations are very specifically oriented and strongly determined by the various positions occupied by the different countries in the art world, some being extremely attractive to artists. In the end, no actual globalization exists in the contemporary art world (Quemin, 200I, 2002a \& b, 2006) if we take the term to mean that all parts of the world are homogenously concerned and that homogenous fluxes are not affected by uneven exchanges or by forms of domination.

So what else can we learn from these two main rankings designed to objectively measure artistic success - the Kunstkompass and the Capital Kunstmarkt Kompass - by concentrating on either the nationality of the artists or 
their countries of residence? Although the national or territorial factor is typically denied by actors from the art world (Quemin, 200I, 2002a), in fact, as the preceding tables all clearly demonstrate, it plays a major role in the consecration process in the contemporary art world. The US always comes first, generally followed by Germany, then the United Kingdom, and, at a further distance, a small group of other nations, generally consisting of France, Italy and Switzerland. All other countries - especially, though not exclusively, those not belonging to the Western world - form a vast periphery. As already mentioned above, the result first discovered some twelve years ago tends to constitute a 'social law,' in Durkheim's terminology, and is still found today in most sectors of the contemporary visual arts field.

\section{THE CERTIFICATION POWER AMONG COUNTRIES: AN UNEVEN DISTRIBUTION}

I shall now show that the predominance of some nationalities in one of the rankings - the Kunstkompass, whose entire methodology is made public occasionally - is similar to the share of the various countries in the construction of the indicator. In particular, the very limited inclusion of non-Western institutions in the elaboration of the ranking helps explain the equally limited presence of non-Western artists in its results. Certification power is still in the hands of a very limited number of countries, a fact often questioned in the contemporary art world but that has not changed significantly in recent years.

I limit my analysis here to two years, $200 \mathrm{I}$ and 2008, which are the only recent years for which I was able to obtain the methodology used by the Kunstkompass, including the lists of institutions yielding points. This information provided an insight into the rankings and their coefficients. Once again, I calculated each country's weight in the construction of the rankings by adding up all coefficients for all institutions from the same country and dividing the figure obtained by the sum of coefficients for all the institutions in the world as a whole that year.

Once again, the most striking result is that at a time when globalization and the disappearance of national borders are supposedly dominating the contemporary art world, the certifying institutions that enable artists to receive points in the Kunstkompass are located in a very small number of countries. In 2008, certifying institutions attributing points in the Kunstkompass were limited to just 2 I countries (out of somewhere between I 90 and 200 nations in the world!). Moreover, although globalization is supposed to be on an ever upward trend, it is ironic to note that the number of countries was actually slightly higher in 200I, reaching a total of 24. Once again this shows how empirical data can be useful in questioning social representations that may differ a great deal from objective reality. 


\begin{tabular}{|c|c|c|}
\hline Country & $\begin{array}{r}\text { Weight in the Production of } \\
\text { the KK in } 2008\end{array}$ & $\begin{array}{l}\text { Weight in } \\
200 \mathrm{I}\end{array}$ \\
\hline Germany & $3 I . I \%$ & $37.3 \%$ \\
\hline USA & $24.2 \%$ & I $6.2 \%$ \\
\hline France & $5.7 \%$ & $6.2 \%$ \\
\hline UK & $5.7 \%$ & $7.4 \%$ \\
\hline Italy & $5.2 \%$ & $4.4 \%$ \\
\hline Austria & $4.8 \%$ & $3.7 \%$ \\
\hline Netherlands & $3.2 \%$ & $3.9 \%$ \\
\hline Switzerland & $3.1 \%$ & $7.0 \%$ \\
\hline Spain & $3.0 \%$ & $4.8 \%$ \\
\hline Japan & $2.1 \%$ & I.I\% \\
\hline Belgium & I. $6 \%$ & I. $4 \%$ \\
\hline Canada & I. $2 \%$ & 1 \\
\hline China & $0.9 \%$ & 1 \\
\hline Greece & $0.9 \%$ & I.I\% \\
\hline Denmark & $0.8 \%$ & $0.9 \%$ \\
\hline Sweden & $0.7 \%$ & I. $6 \%$ \\
\hline Ireland & $0.6 \%$ & 1 \\
\hline Luxemburg & $0.4 \%$ & 1 \\
\hline Poland & $0.4 \%$ & $0.2 \%$ \\
\hline Czech Republic & $0.4 \%$ & $0.5 \%$ \\
\hline Russia & $0.4 \%$ & $0.2 \%$ \\
\hline South Korea & $0.4 \%$ & 1 \\
\hline India & $0.4 \%$ & I \\
\hline Brazil & $0.3 \%$ & 1 \\
\hline $\mathrm{UAE}$ & $0.3 \%$ & 1 \\
\hline Turkey & $0.3 \%$ & $0.2 \%$ \\
\hline Finland & $0.3 \%$ & 1 \\
\hline Portugal & $0.3 \%$ & $0.5 \%$ \\
\hline Mexico & $0.3 \%$ & 1 \\
\hline Ukraine & $0.3 \%$ & 1 \\
\hline Thailand & $0.3 \%$ & 1 \\
\hline South Africa & $0.3 \%$ & 1 \\
\hline Australia & I & $0.4 \%$ \\
\hline Norway & I & $0.3 \%$ \\
\hline Argentina & I & $0.3 \%$ \\
\hline Denmark & I & $0.2 \%$ \\
\hline Slovenia & I & $0.2 \%$ \\
\hline
\end{tabular}

Table 5

Contribution of countries to the construction of the

Kunstkompass in $200 \mathrm{I}$ and 2008 
Furthermore, just as in the other tables already discussed in this article, the share of the various countries is very uneven. Germany comes far ahead of all other countries in terms of contributing to the calculation of the Kunstkompass and the country's weight seems to be highly exaggerated. It accounted for no less than $31 . \mathrm{I} \%$ of the indicator in 2008 and as high as $37.3 \%$ in $200 \mathrm{I}$. Considering the fact that, in most countries, national institutions tend to present more national artists than international, it is little wonder that German artists are ranked so highly in the Kunstkompass list. Unsurprisingly the country with the second highest weighting in the calculation of the Kunstkompass - at a clear distance from Germany, but still far ahead of the third place - is the USA. Its share in the construction of the indicator was $16.2 \%$ in $200 \mathrm{I}$ but this figure rose markedly to $24.2 \%$ in 2008 . Interestingly enough, the decline in Germany's share benefited its only challenger in the construction of the ranking and not any of the other countries, including the most peripheral. At a clear distance from the USA comes a group of four countries whose contribution in the elaboration of the indicator is fairly similar: the UK, France, Italy and Austria. Although the differences between the four nations were a bit more marked in 200I, ranging from 7.4\% for the United Kingdom to 3.7\% for Austria, in 2008, the gap between the same two nations at each end of the group was much closer, $5.7 \%$ and $4.8 \%$ respectively. For the remaining countries, the share of those outside Western Europe, the USA and Canada is extremely low in terms of calculating the Kunstkompass: $3.1 \%$ only in $200 \mathrm{I}$ and $6.5 \%$ in 2008 ! As we can see, the share of non-Western countries tended to rise at the beginning of the millennium but still remains extremely limited.

To illustrate the link between the weight of the various countries in calculating the Kunstkompass and the presence of their artists in the eventual results of the rankings, I decided to present the figures for the two recent years for which information was available on the construction of the indicator. Very often the same countries are represented through their institutions and thus impact on the designation of artists at international level. As a consequence, their national artists appear in the result of the ranking. This may be because the countries concerned offer a vibrant contemporary art scene that includes both highly successful artists and art institutions with international influence, or because their presence in the calculations for the indicator favors their artists' appearance in the final list. Neither explanation excludes the other, of course. 


\begin{tabular}{|c|c|c|c|c|c|c|}
\hline & Calculation & Result & Eff. Coeff & Calculation & Result & Eff. Coeff \\
\hline Countries & $200 I$ & $200 I$ & $200 \mathrm{I}$ & 2008 & 2008 & 2008 \\
\hline Germany & $37.3 \%$ & $27.0 \%$ & 0.72 & 3I.I\% & $32.0 \%$ & I.03 \\
\hline USA & I $6.2 \%$ & $34.9 \%$ & 2.15 & $24.2 \%$ & $28.6 \%$ & I.I 8 \\
\hline France & $6.2 \%$ & $3.7 \%$ & 0.60 & $5.7 \%$ & $3.8 \%$ & 0.67 \\
\hline UK & $7.4 \%$ & $6.3 \%$ & 0.85 & $5.7 \%$ & IO.I\% & I.77 \\
\hline Italy & $4.4 \%$ & $4.4 \%$ & 1.00 & $5.2 \%$ & $2.7 \%$ & 0.52 \\
\hline Austria & $3.7 \%$ & $2.8 \%$ & 0.76 & $4.8 \%$ & $2.5 \%$ & 0.52 \\
\hline Netherlands & $3.9 \%$ & $0.7 \%$ & & $3.2 \%$ & I. $5 \%$ & 0.47 \\
\hline Switzerland & $7.0 \%$ & 4.I\% & 0.59 & $3.1 \%$ & $3.2 \%$ & 1.03 \\
\hline Spain & $4.8 \%$ & I & & $3.0 \%$ & $0.7 \%$ & \\
\hline Japan & I.I\% & $2.1 \%$ & I.9I & $2.1 \%$ & $0.7 \%$ & \\
\hline Belgium & I. $4 \%$ & $0.7 \%$ & & I. $6 \%$ & I. $8 \%$ & I.I3 \\
\hline Canada & I & I. $9 \%$ & & I. $2 \%$ & $2.5 \%$ & 2.08 \\
\hline China & I & 1 & & $0.9 \%$ & 1 & \\
\hline Greece & I.I\% & $1.0 \%$ & $0.9 \mathrm{I}$ & $0.9 \%$ & $0.8 \%$ & \\
\hline Denmark & $0.9 \%$ & $0.7 \%$ & & $0.8 \%$ & I. $5 \%$ & \\
\hline Sweden & I. $6 \%$ & I & & $0.7 \%$ & 1 & \\
\hline Ireland & 1 & I & & $0.6 \%$ & 1 & \\
\hline Luxemburg & 1 & I & & $0.4 \%$ & & \\
\hline Poland & $0.2 \%$ & I & & $0.4 \%$ & 1 & \\
\hline Czech Rep. & $0.5 \%$ & I & & $0.4 \%$ & & \\
\hline Russia & $0.2 \%$ & I. $7 \%$ & & $0.4 \%$ & I.I\% & \\
\hline South Korea & I & I. $3 \%$ & & $0.4 \%$ & & \\
\hline India & I & I & & $0.4 \%$ & 1 & \\
\hline Brazil & 1 & I & & $0.3 \%$ & 1 & \\
\hline UAE & I & l & & $0.3 \%$ & 1 & \\
\hline Turkey & $0.2 \%$ & l & & $0.3 \%$ & 1 & \\
\hline Finland & l & l & & $0.3 \%$ & 1 & \\
\hline Portugal & $0.5 \%$ & I & & $0.3 \%$ & & \\
\hline Mexico & I & $0.8 \%$ & & $0.3 \%$ & $0.9 \%$ & \\
\hline Ukraine & 1 & I & & $0.3 \%$ & I & \\
\hline Thailand & I & $0.8 \%$ & & $0.3 \%$ & $0.8 \%$ & \\
\hline South Africa & I & $1.0 \%$ & & $0.3 \%$ & I. $4 \%$ & \\
\hline Australia & $0.4 \%$ & $0.7 \%$ & & I & 1 & \\
\hline Norway & $0.3 \%$ & I & & l & 1 & \\
\hline Argentina & $0.3 \%$ & I & & I & 1 & \\
\hline Denmark & $0.2 \%$ & I & & I & 1 & \\
\hline Slovenia & $0.2 \%$ & I & & I & 1 & \\
\hline Serbia & I & $0.7 \%$ & & I & $0.8 \%$ & \\
\hline Iran & I & $0.9 \%$ & & I & I.O\% & \\
\hline Iceland & I & $1.0 \%$ & & I & 1 & \\
\hline Cuba & I & $0.7 \%$ & & I & $0.7 \%$ & \\
\hline Albania & 1 & 1 & & I & $0.7 \%$ & \\
\hline
\end{tabular}

Table 6

Share of each country in the calculation mode of the Kunstkompass in $200 \mathrm{I}$ and 2008, result in terms of the share of artists of each country in the indicator and the 'efficiency coefficient' in $200 \mathrm{I}$ and 2008 
Although there is already a general link between the presence of a country in the calculation mode of the Kunstkompass and the representation of artists in the ranking, the link itself would be even stronger were country of residence taken into account rather than - as in the case of the Kunstkompass - nationality. For instance, it is no surprise that Serbia is represented in the results of the Kunstkompass both in $200 \mathrm{I}$ and 2008, even though the country had no certifying institutions in the ranking for either of two years, since its only 'national' artist then was Marina Abramovic, who lived for decades in the Netherlands and now lives in the USA, two countries that were both represented in the calculation mode of the Kunstkompass both in 200I and 2008. The same can be said for Albania, represented solely by Anri Sala who lived in France at the time, as well as Iran - with Shirin Neshat living in the USA - and Iceland and Cuba. Generally speaking, when the weight of the countries is significant in the calculation mode of the Kunstkompass, the presence of national artists in the ranking appears to be quite systematic, but when it is low, the favorable effect linked to the presence of national artists in the ranking seems to decline.

Still, despite this general tendency, the fact that the link between national contributions to the calculation mode of the ranking and presence of national artists in the resulting top roo is not entirely systematic can also be illustrated by the uneven efficiency - that is to say positive influence - of the presence of the various countries in the elaboration of the ranking. For all those countries whose contribution to the calculation of the Kunstkompass is higher than $\mathrm{I} \%$ or whose artists account for more than $\mathrm{I} \%$ of international artistic production as synthesized in the ranking, we calculated an efficiency ratio by dividing the weight of artists of a given country by the weight of the same country in the calculation mode of the indicator. The results show extremely marked differences between nations. In 200I, Germany showed a counter-performance (an efficiency ratio of 0.72 only) with its artists doing less well than might be expected were we to consider the country's share in the calculation mode of the Kunstkompass. However, the situation evolved strongly and by 2008 the result of German artists had become proportional to the presence of Germany in the elaboration of the indicator (I.03) - that is to say, somewhat overrated given the still excessive contribution of German institutions to calculating the Kunstkompass.

In 200I, the efficiency coefficient of the USA was excellent: 2.I5. It fell to a more subdued performance of I.I 8 'only' - still positive though - in 2008, probably because more foreign artists joined the American art scene and these are still considered foreigners by the Kunstkompass. This tends to lessen the American performance, which would otherwise be much better. The very satisfactory score achieved by the USA is a clear sign of the strong legitimacy of American artists - and artists living in the USA - on the international contemporary art scene. 
In 200I, the efficiency coefficient of the United Kingdom was below I (0.85), which showed some weakness, but rose to $\mathrm{I} .77$ in 2008 , a sign of the strengthening of British artists on the international art scene during the first decade of the millennium.

By contrast, the situation is worrying for Italy and France. In 200I, the presence of Italian artists in the Kunstkompass was proportional to the contribution of the country in the indicator (I.O), but it degraded heavily in less than a decade to reach just 0.52 in 2008 , a sign of the decline in the Italian artistic presence internationally over recent years. France also faces a worrying situation with efficiency rates of 0.60 and 0.67 only in $200 \mathrm{I}$ and 2008 , revealing that its artists do far worse than what might be expected given the influence of French institutions in the international contemporary art scene. As I have shown in previous works, France and Italy have experienced a declining vitality in this area since the beginning of the I970s. This is probably due to bad strategic choices with each of the countries reinforcing its connections - for example in terms of artists being exhibited in its main museums - with the other country at a time when both were encountering a certain decline on the global scene and becoming more peripheral, thus accentuating their mutual decline. Moreover, France's loss of its central position on the art market, which was long concentrated in the country but shifted away from it in the r 960 , had devastating effects for the French scene and artists. Hence, while success generally begets success (Merton, I968), at least in the short term, in the longer term, evolutions among countries are perfectly possible, as shown by Germany's progress in the I980s, the UK's in the 2000s, and the slow decline experienced by France and Italy since the I970s. ${ }^{12}$

\section{THE ARTREVIEW POWER 100}

After studying the share of the different countries in the construction mode of the Kunstkompass, I now turn to a third indicator: the ArtReview Power roo. This list aims to objectively identify the most influential or powerful actors in the contemporary art world - that is, the players who can influence the very uneven success and consecration of artists examined earlier.

Analyzing the weight of the various countries in the construction of the Kunstkompass reveals a homology (Bourdieu, I989) between the share of the different nations in the construction of the indicator through their certifying institutions and the share of their national artists in the list. Is this finding corroborated by the analysis of another indicator, the Power Ioo? The Power Ioo ranks the alleged roo most powerful figures in the contemporary art world in a list that, unlike the previous two analyzed earlier in this article, extends far beyond artists to include collectors, gallerists, museums directors, curators, critics and so on. 


\section{The methodology}

Once again, I quickly need to present the methodology of the Power Ioo before analyzing this indicator from a sociological perspective. It may be worth stressing here that the methodology used to elaborate the Power Ioo seems to be rather loose. The authors state that they ask experts from the art world to name who they consider to be the most powerful personalities in the contemporary art domain. However it seems that the authors mostly ask the journal's collaborators and there are no indications to the identity (or even general characteristics) of the respondents, or even how many there are. Although this is somewhat frustrating for the social scientist who wishes to know more about these features, it should be emphasized that the rankings are plausible enough for the Power Ioo to have been published for 12 years now and still retain legitimacy in the art world. Besides, one of the findings of my work on fame in the art world (Quemin, 2013b) has been that, when it comes to consecration, the impact of methodologies is rather limited. Despite the very different methodologies used by the Kunstkompass and the Capital Kunstmarkt Kompass, for instance, with the use of a much more substantial methodology by the second indicator, when it comes to the top of the rankings, the differences between the two lists are very small. It is as though consecration imposes itself on analysts whatever methodology is used and whatever its complexity. Moreover, like all rankings that possess a high visibility and legitimacy in the contemporary art world, the Power roo plays a performative function and partly creates the reality that it is merely supposed to reveal.

The Power Ioo was first published in 2002 in a British magazine, The ArtReview, and has been published on a yearly basis ever since. Although it is only supposed to show who the most important players of the art world are each year, its repeated publication also offers a valuable observation tool for determining the extent to which power is stable over time. Furthermore, as the names of the art figures listed in the Power roo are accompanied by a short biography, it is also possible to analyze the characteristics of the major players from the contemporary art world: for instance, in terms of activity (gallerist, collector, artist...), gender (Quemin, 2013b) or nationality (or country of residence), and how these characteristics have evolved over time.

In all these domains, the Power Ioo enables us to test Bourdieu's hypothesis of a homology (I989) between the characteristics of the judges and those being judged - in terms of gender (Quemin, 2013b), for example, but also in terms of nationality, the topic that interests us in this article.

First of all, I analyzed the nationalities of all personalities listed in the Power Ioo between 2006 and 20I2. In all, 239 different players appear on the lists between these two dates with many of them staying for several or indeed many years (Quemin, 20I3b). 


\begin{tabular}{l|r}
\hline USA & $35.0 \%$ \\
\hline Germany & I3.0\% \\
\hline UK & I $2.3 \%$ \\
\hline Switzerland & $6.2 \%$ \\
\hline France & $5.4 \%$ \\
\hline Italy & $2.9 \%$ \\
\hline Eastern Europe & $3.8 \%$ \\
\hline Canada & $0.6 \%$ \\
\hline Latin America & $3.5 \%$ \\
\hline Asia & $5.6 \%$ \\
\hline Middle East & $3.6 \%$ \\
\hline Oceania & $0.4 \%$ \\
\hline Africa & $0.4 \%$ \\
\hline
\end{tabular}

Table 7

Breakdown of personalities in the ArtReview Power Ioo from 2006 until 2012 by country or groups of countries

Once again, power in the contemporary art world seems to be concentrated in the hands of a small group of countries. This result is very different from the usual discourse on globalization and the erasure or disappearance of borders in the contemporary sphere. Moreover, these countries are the same as those encountered when I tried to objectively determine the most successful countries in terms of artistic fame. As in nearly all cases, the USA comes first, a considerable distance from its usual challengers, Germany and the United Kingdom. It should be pointed out here that since the Power roo is elaborated by a team of British journalists, the influence of British players in the contemporary art world seems to be overestimated, just like the influence of German institutions has tended to be overestimated by German journalists elaborating the Kunstkompass. The USA, Germany and the United Kingdom, which respectively concentrate $35.0 \%, \mathrm{I} 3.0 \%$ and I $2.3 \%$ of all personalities listed in the Power Ioo between 2006 and 2012, dominate all other countries, as frequently registered earlier in this article. These are followed by a group of three countries also often encountered together and whose positions tend to be quite similar: Switzerland accounts for $6.2 \%$, France for $5.4 \%$ and Italy for $2.9 \%$. Combined these six countries account for no less than three-quarters of the power in the international contemporary art world. The share of other Western European countries is limited to $6.4 \%$, Eastern Europe to 3.8\%, Asia 5.6\%, the Middle East 3.6\%, Latin America 3.5\%, and Africa and Oceania just $0.4 \%$ each. Of course, it could be argued that the concentration on the Western sphere is partly due to the fact that the ranking is produced in a Western country. Still, this does not 
concern all Western countries indifferently but rather always the same leading nations in the same region of the world. A vast majority of Western countries also occupy a peripheral position on the international art scene. Even though China - to take just one example of an important non-Western country - has become a key player in the international contemporary art market, it has not even tried to develop a ranked list of the most powerful or influential players in the contemporary art world that could rival the one elaborated and published by the ArtReview team.

One surprising trait of the Power Ioo is that - unlike the previous rankings of artists explored earlier in the article, which proved very stable over time, reflecting that success generally begets success (Merton, I968) - the turnover of personalities listed in the Power Ioo is especially high. In contrast to the Kunstkompass, where turnover is generally around $5 \%$ from one year to the next, the turnover rate in the Power Ioo can be as high as $30 \%$ ! Even so, a downward trend was noted to the rate, which reached $28 \%$ in 2007 and as high as $35 \%$ in 2008 , but fell to $24 \%$ in 20 I I and 'just' I7\% in 2012 (Quemin, 20I3b). It may be considered surprising that players who are supposed to hold the power in the contemporary art world and who are listed as such in the Power roo do not appear in the ranking on a permanent basis. Given the high turnover to the Power I ००, I decided to elaborate a new 'ranking of the rankings' by compiling the information for the years 2006 to 2012, taking into account the number of appearances of each actor from the contemporary art world during those seven years and calculating the average rank of all players appearing between one and seven times. I then decided to focus on the top roo personalities from the new ranking and study their characteristics. Here I shall focus on their nationalities.

The main difference when comparing the nationalities of the top players from the contemporary art world with all the actors listed at least once in the ArtReview Power Ioo listings is that the United Kingdom share increases very significantly from $12.30 \%$ to $20.30 \%$, which probably illustrates the bias in favor of British actors remarked upon earlier. Otherwise the overall lines of the previous analysis remain unchanged. When we compare the nationalities of the personalities that appear in the ranking with those of the artists who are selected, focusing simultaneously on the most frequently represented countries and on the non-Western world, a strong correlation emerges. This offers a good illustration of Bourdieu's hypothesis of homology (Bourdieu, I989) between those who label (Becker, I982) works as contemporary art and consecrate artists, on one hand, and those who become consecrated, on the other, when we take into account the national or territorial factor. In terms of artistic consecration, certification power is still concentrated in the hands of a small number of institutions and players, nearly all Western: they still mostly promote Western artists belonging to a very limited number of countries with strong concentration effects on the United Kingdom, Germany and especially the USA. 


\begin{tabular}{l|rr}
\hline Country & Top players & (At least one appearance) \\
\hline USA & $35.70 \%$ & $35.00 \%$ \\
\hline United Kingdom & $20.30 \%$ & I $2.30 \%$ \\
\hline Germany & I $3.00 \%$ & I $3.00 \%$ \\
\hline Italy & $6.00 \%$ & $2.90 \%$ \\
\hline Switzerland & $5.80 \%$ & $6.20 \%$ \\
\hline France & $4.00 \%$ & $5.40 \%$ \\
\hline China & $2.50 \%$ & $3.10 \%$ \\
\hline Russia & I.30\% & I.40\% \\
\hline Mexico & I.30\% & I.40\% \\
\hline Austria & I.00\% & $0.80 \%$ \\
\hline Sweden & I.00\% & $0.80 \%$ \\
\hline Greece & I.00\% & $0.80 \%$ \\
\hline Poland & I.00\% & $0.80 \%$ \\
\hline Canada & I.00 \% & $0.60 \%$ \\
\hline Serbia & I.00\% & $0.40 \%$ \\
\hline Ukraine & I.00\% & $0.40 \%$ \\
\hline Japan & I.00 \% & $0.40 \%$ \\
\hline Venezuela & I.00\% & $0.40 \%$ \\
\hline South Africa & I.00\% & $0.40 \%$ \\
\hline Rest of the world & $14.90 \%$ \\
\hline
\end{tabular}

Table 8

Breakdown of the top Ioo most powerful players from the international contemporary art world from 2006 to 2012 in the ArtReview Power Ioo (and comparison with the breakdown of countries of the 239 players appearing at least once in the lists)

\section{WHAT ABOUT THE MARKET?}

Finally we can analyze whether the star artists - as they are called - listed in the rankings are the same as the most successful artists on the art market, or whether, at least, they share similar characteristics in terms of nationality. First this enables us to test Raymonde Moulin's hypothesis that art value is created where the art institutions and the art market converge (Moulin, I992). For this purpose, I compared the first two rankings, the Kunstkompass and the Artfacts Kunstmarkt Kompass, with two indicators of success on the art market. Since private transactions between the walls of art galleries and their booths at art fairs remain discreet, we had to 
concentrate on data relating to auctions. We chose two sources, the ranking of the 500 top selling artists annually published by Artprice for the contemporary sector (Artprice, 20I2) and the artists most present in Christie's and Sotheby's prestige May and November contemporary art sales, held in both London and New York City. As a matter of fact, in both cases, the link between success or visibility in institutions measured by the Kunstkompass and Artfacts Kunstmarkt Kompass, on one hand, and market indicators, on the other, is rather weak and tends to invalidate Raymonde Moulin's theory, at least in relation to top artists and recent years (Quemin, $2013 b)$. Lists of star artists for the market and for institutions tend to diverge considerably. This is all the more noticeable in the case of the Artfacts ranking where some elements connected to the market - presence in art galleries and gallery shows - are used in the calculation mode of this indicator.

In particular, the sudden explosion of China on the auction market from 2007 onwards (Quemin, 20I4d) resulted in a strong disconnection emerging between star artists as they are identified and produced by institutions - the most central of which are still overwhelmingly located in the Western world - and the most successful artists on the art market. Although no less than $45 \%$ of living contemporary artists fetching the highest prices at auctions in 2012 were Chinese, the presence of Chinese artists in rankings that exclusively or primarily express institutional visibility remained extremely limited. In 2012, Chinese artist Ai Weiwei 3 was ranked 89th in the Kunstkompass and there was no Chinese artist in the top roo living artists from the Artfacts ranking. Unlike real superstars such as Gerhard Richter, Andreas Gursky or Jeff Koons, who generally combine institutional success and record prices at auctions, Chinese artists, even when they achieve tremendous success on the market, still encounter difficulties in being included on the programs of the most prestigious (Western) contemporary art institutions. Furthermore, while the tremendous market success of Chinese artists very significantly opened up the field to non-Western artists, it was limited to the market and mostly just one segment of it, namely the auctions (revealingly enough, there are no important Chinese contemporary art galleries). I 4 In addition, this spectacular breakthrough did not make a huge difference in terms of opening the field to other non-Western countries. Aside from the major success of Chinese artists at art auctions, mostly organized in China and aimed at Chinese buyers, the most successful artists on the 'real' international art market remain American, German or British, once again confirming the central positions of these countries in the contemporary art world. 


\section{CONCLUSION}

Although actors in the contemporary art world generally tend to deny it, nationality and territory have a major effect on fame and on the artistic consecration process. This is true when we consider an indicator like the Kunstkompass but also when referring to others with much more complex methodologies - and probably with less biases, notably in terms of nationalities - such as the Capital Kunstmarkt Kompass elaborated by Artfacts. Far from being present anywhere on the surface of the planet or coming from any region or continent, the most recognized artists generally belong to a very small number of countries that are all Western and among which the United Kingdom and Germany, but even more so the USA, take the lion's share. A similar phenomenon of concentration among a very small number of leading nations in the contemporary art sector can be found, with the same countries playing the central roles, when we turn to study the most influential art institutions - through the Kunstkompass methodology - or the most powerful players in the contemporary art world, through the personalities listed in the ArtReview Power ıoo. The most famous international artists belong to a very select number of countries and likewise the players who elect them, whether these are institutions or individual actors. Moreover, these countries are quite systematically the same, forming the core of the contemporary art world. As far as the market is concerned, at least its auction sector, the field has been massively opened to the non-Western world with the sudden explosion of Chinese art in 2007. However, this has not really opened up the international art scene to other countries and the presence of Chinese artists at the most prestigious contemporary art sales organized by Christie's and Sotheby's remains extremely scarce, showing that even in this sector, territorial factors continue to play a central role. 
850

Alain Quemin is Professor of Sociology (exceptional class) at the Université de Vincennes - Paris 8/Institut d'Etudes Européennes and a researcher at Labtop-CRESPPA, based at the French National Center for Scientific Research (CNRS). He is also an honorary member of Institut Universitaire de France, former president of Research Committee 37 (Sociology of the Arts) for the International Sociological Association, and former vice-president of the Sociology of Arts Research Network of the European Sociological Association. His specialization is in the sociology of art markets and institutions, globalization and the arts, and artistic fame and consecration. 


\section{ENDNOTES}

I This article has been adapted from Quemin 20I3c.

2 I found about 70 rankings that can be analyzed sociologically in order to understand how fame is constructed in the contemporary art world and how it works, and to empirically test theories that seek to explain artistic careers and artistic value (Quemin, 2013b).

3 It seems that the first edition of the book covered the lives and works of just 29 dead or living artists. In later versions of the publication, the number of artists rose markedly.

4 In this article, contemporary art is taken to be defined as such by the informal academies that control the contemporary art world (Becker, I982). Some chronological criteria are generally adopted, usually works from I 945 or I 970 onward. More fundamentally, though, not all the art works produced within this time range are held to be contemporary and informal academies have to agree on what is really contemporary (Moulin, I992; Quemin, 200I).

5 In fact, prior to the creation of the Kunstkompass in I970, the first real ranking of artists was published by French art magazine in I 955 (the journal itself was founded in I952). Only 5 rankings were published, however: in I955, I96I, I966, I97 I and 1976. The methodology was also rather loose and involved consulting 'experts' in the art world (Verger, I987). It should be mentioned here that although museum directors and curators tend to consider 1970 as the date of birth for contemporary art as a category, art historians adopt a different convention, identifying the year I945. In both cases, the emergence of contemporary art as a category is more or less simultaneous to the creation of artist rankings.

6 A similar profusion of rankings can be observed in many other domains of social life (Nelson Espeland \& Sauder, 2007) dating from the I970s: "In the past two decades, demands for accountability, transparency and efficiency have prompted a flood of social measures designed to evaluate the performances of individuals and organisations" (p. I); "The proliferation of quantitative measures of performance is a significant social trend" (p. 2); "All trends suggest that 
organisational rankings will spread and become more encompassing" (p. 8).

7 Although in theory the methodology is available on demand, our requests have generally been ignored.

8 The figures for the period from 1994 to 2006 can be found in Quemin, 2013b.

9 With the exception of 2009 when the Kunstkompass methodology was probably redesigned, which caused huge - but only temporary - changes in the results (see Quemin, 20I3b).

Io Two artists divide their time between their country of birth and another.

I I The lists of institutions included in the construction of the Kunstkompass in $200 \mathrm{I}$ and 2008, together with the corresponding coefficients, can be found in Quemin, 2013b.

I 2 More marked evolutions such as the rise and fall of countries over the longer term are analyzed in Quemin, 2002, including an analysis of the different factors that may help explain these phenomena.

I 3 It may be useful to point out that Ai Weiwei lived for many years in the Western world before returning to China. His familiarity with the American contemporary art world and its norms may have facilitated his access to international success.

I4 Although some of the most successful Chinese artists are represented by prestigious European and American galleries, including Gagosian, Pace or White Cube, they always constitute a minority in their rosters, and indeed only represent a tiny part of them, especially when their numbers are compared to American or even German or British artists. 


\section{BIBLIOGRAPHY}

Artprice. (20I2), Le marché de l'art contemporain 20I I-20I 2: le rapport annuel Artprice. Available at <http://imgpublic. artprice.com/pdf/artprice-contemporary-20I I-20 I 2-fr. pdf $>$. Accessed I I/29/20I5.

Bartelson, Jens. (2000). Three concepts of globalization. International Sociology, I5/2, p. I80-I96.

Becker, Howard. (I982). Art worlds. Berkeley/Los Angeles: University of California Press.

Bellavance, Guy (Ed.). (2000). Monde et réseaux de l'art: diffusion, migration et cosmopolitisme en art contemporain. Montreal: Liber.

Bourdieu, Pierre. (1989). La noblesse d'Etat: grandes écoles et esprit de corps. Paris: Éditions de Minuit.

Bourdieu, Pierre. (1993). Sociology in question. London: Sage. Bourdieu, Pierre, Darbel, Alain \& Schnapper, Dominique. (I997). The love of art: European art museums and their public. Oxford: Polity Press.

Bowness, Alan. (1989). The conditions of success: how the modern artist rises to fame. London: Thames \& Hudson.

Merton, Robert. (I968), The Matthew effect. Science, I59/38Io, p. 56-63.

Moulin, Raymonde. (1987). The French art market: a sociological view. New Brunswick: Rutgers University Press.

Moulin, Raymonde. (1992). L'artiste, l'institution et le marché. Paris: Flammarion.

Moulin, Raymonde \& Quemin Alain. (I993). La certification de la valeur de l'art: experts et expertises. Annales ESC, special issue Mondes de l'art, 48/6, p. I42 I - I 445.

Nelson Espeland, Wendy \& Sauder, Michael. (2007). Rankings and reactivity: how public measures recreate social worlds. American Journal of Sociology, I I3/ I, p. I-40.

Piles, Roger de. (I 969) [I708]. Cours de peinture par principes. Genève: Slatkine Reprints

Quemin, Alain. (200I). Le rôle des pays prescripteurs sur le marché et dans le monde de l'art contemporain. Paris: Ministère des Affaires Etrangères. 
Quemin, Alain. (2002a) L'art contemporain international: entre les institutions et le marché. Nimes/Lyon: Jacqueline Chambon/Artprice.

Quemin, Alain. (2002b). L'illusion de l'abolition des frontières dans le monde de l'art contemporain international: la place des pays 'périphériques' à l'ère de la globalisation et du métissage. Sociologie et Sociétés, XXXIV/2, p. I5-40.

Quemin, Alain. (2006). Globalization and mixing in the visual arts: an empirical survey of 'high culture' and globalization. International Sociology, 2 I/4, p. 522-550.

Quemin, Alain. (2012). The internationalization of the contemporary art world and market: the role of nationality and territory in a supposedly 'globalized' sector. In: Lind, Maria \& Velthuis, Olav (Eds.). Contemporary art and its commercial markets. Berlin: Sternberg Press, p. 53-84

Quemin, Alain. (2013a). International contemporary art fairs in a 'globalized' art market. European Societies, I5/2, p. I62-I77.

Quemin, Alain. (2013b). Les stars de l'art contemporain. Paris: Editions du CNRS.

Quemin, Alain. (2013c). From 'national creativity' to social recognition and success in the visual arts: a sociological perspective on rankings of the "Top roo Artists in the World". In: Chan Jerry \& Thomas Kerry (Eds.). Handbook of research on creativity. Cheltenham, UK/Northampton, MA: Edward Elgar Publishing, p. 230-248

Quemin, Alain. (2013d). La Chine et l'art contemporain: l'arrivée de l'Empire du Milieu dans le monde et sur le marché de l'art. In: Bret, Jean-Noël \& Moureau, Nathalie. (Eds.). L'art, l'argent et la mondialisation. Paris: L'Harmattan, p. 77-98.

Rohr-Bongard, Linde (Ed.) (200I). Kunst = Kapital. Der Capital Kunstkompass von 1970 bis heute. Köln: Salon Verlag.

Therborn, Goran. (2000). Globalizations: dimensions, historical waves, regional effects, normative governance. International Sociology, I5/2, p. I5I-I79.

Vasari, Giorgio. (I550). Le vite de' più eccellenti pittori, scultori, e architettori da Cimabue insino a' tempi nostri. Florence: Lorenzo Torrentino. 
van Hest, Femke. (20I2). Territorial factors in a globalized art world? The visibility of countries in international contemporary art events. Doctoral Dissertation. Erasmus Universiteit Rotterdam/École des Hautes Études en Sciences Sociales. Rotterdam: ERMeCC.

Velthuis, Olav. (2013). Globalization of markets for contemporary art: why local ties remain dominant in Amsterdam and Berlin. European Societies, I5/2, p. 290-308.

Velthuis Olav \& Baia Curioni, Stefano (Eds.). (20I5). Cosmopolitan canvases: the globalization of markets for contemporary art. Oxford: Oxford University Press.

Verger, Annie. (1987). L'art d'estimer l'art: comment classer l'incomparable?. Actes de la Recherche en Sciences Sociales, 66-67, p. I05-I 2 I.

Villas Bôas, Glaucia \& Quemin, Alain (Eds.). (20I5). Art et société. Marseille: Open Edition Press. 


\section{O IMPACTO DA NACIONALIDADE NO MERCADO DE ARTE CONTEMPORÂNEO}

\begin{abstract}
Resumo
A nacionalidade e o território afetam grandemente a fama artística, embora os atores no mundo contemporâneo da arte tendam a negar o fato. Os artistas mais reconhecidos geralmente pertencem a um seleto número de países ocidentais entre os quais o Reino Unido e a Alemanha, mas também os Estados Unidos, e ganham a parte do leão. Isso se reflete na representação desigual dos países na elaboração de classificações como a Kunstkompass, utilizada para objetivar a fama e visibilidade dos artistas. O número muito pequeno de países que concentram os artistas mais famosos também indica a homologia com a nacionalidade dos mais poderosos atores do mundo artístico contemporâneo, tal como relacionado na ArtReview Power ıoo. Na conclusão, mostro que, ao menos para os anos recentes dos principais artistas, as nacionalidades daqueles mais evidenciados em instituições e daqueles mais bem sucedidos no mercado divergem.
\end{abstract}

\section{THE IMPACT OF NATIONALITY ON THE CONTEMPORARY ART MARKET} all Western and among which the United Kingdom and Germany, but even more so the USA, take the lion's share. This reflects the uneven representation of countries in the elaboration of rankings, like the Kunstkompass, used to objectivize the fame and visibility of artists. The very small number of countries concentrating the most famous artists also shows a homology with the nationality of the most powerful players from the contemporary art world, as listed in the ArtReview Power Ioo. In concluding the article, I show that, at least for top artists over recent years, the nationalities of the most visible artists in institutions and those of the most successful artists on the artists on the market diverge.
Palavras-chave

Mercado de arte;

Reputações;

Fama;

Hierarquias;

Globalização.

Keywords

Art market;

Reputations;

Fame;

Rankings;

Globalization. 